\title{
KONSTRUKSI SOSIAL ANAK JALANAN PEREMPUAN DI KOTA PEKANBARU
}

\author{
Oleh: Yesi \\ Fakultas Ilmu Sosial dan Ilmu Politik,Universitas Riau
}

\begin{abstract}
Abstrak
Terdapat 120 anak jalanan perempuan di Pekanbaru yang umumnya berusia 615 tahun serta bekerja menjual tissue, pengemis, jasa semir sepatu, penjual koran, pedagang asongan, dan pengamen.Tujuan penelitian melihat konsep diri anak jalanan menggunakan perspektif konstruksi social. Pendekatan yang digunakan yaitu kualitatif deskriptif dengan teknik penetuan subjek diawali accidental sampling yang kemudian diteruskan dengan purposive sampling. Hasil penelitian terhadap 6 (enam) subjek diketahui proses eksternalisasi terdiri dari dua model. Pertama, eksternalisasi lingkungan terhadap orang terdekat dan kemudian diwariskan kepada subjek. Kedua, eksternalisasi yang kaitannya secara langsung oleh subjek dengan realitas atau keadaan sekitarnya tanpa adanya proses pewarisan. Subjek dengan sendirinya tertarik karena melihat kebiasaan yang dilakukan secara berulang dan diajak untuk turut bekerja bersama sehingga hal itu memicu ketertarikan menjalankan pekerjaan serupa. Objektivasi dilakukan dengan merubah penampilan dengan tambahan property pendukung. Internalisasi terjadi pada titik subjek merasa nyaman dan menyatu dengan pekerjaannya. Subjek sudah merasa sangat nyaman dan terbiasa dengan lingkungan pekerjaannya meskipun orang-orang menganggap penuh dengan resiko.
\end{abstract}

Kata Kunci: Anak Jalanan, Konstruksi Sosial, Perempuan.

\section{PENDAHULUAN}

Ada hal yang menarik ketika kita mengamati sepintas kehidupan di perkotaan. Sebagai kawasan yang cenderung ramai, kota merupakan tempat tujuan banyak orang dari daerah-daerah pedesaan untuk mengadu nasib. Datang dari berbagai macam daerah di penjuru negeri, mereka berharap sesampainya di kota akan mendapat pekerjaan sekaligus pendapatan layak untuk meningkatkan taraf kehidupan diri sendiri maupun keluarga di kampung. Jenis pekerjaannya bisa beragam, berdasarkan kemampuan serta kompetensi diri seperti buruh pabrik, karyawan perusaan, tukang tambal ban, cleaning service, buruh bangunan, berdagang, dan masih banyak lagi.

Untuk di Pekanbaru, sesuai dengan hasil survey yang dilakukan pada penelitian pertama ditemukan ada sebanyak 120 anak jalanan perempuan di Pekanbaru yang menekuni berbagai macam pekerjaan jalanan. Survey ini dilakukan secara random di seluruh daerah keramaian Pekanbaru untuk mendapatkan data yang valid. Observasi lapangan juga menemukan beberapa kelompok anak jalanan yakni mereka yang masih memiliki orang tua, tidak memiliki orang tua, tinggal bersama orang tua, dan tinggal bebas di jalanan (Basri \& Yoserizal, 2019). Anak jalanan perempuan merupakan kelompok rentan mendapatkan kekerasan (Siswanto \& Widodo, 2019) baik fisik maupun psikologis. Ini dialami oleh mereka baik karena lingkungan eksternal maupun tekanan dan kekerasan yang muncul dari internal anak jalanan 
perempuan. Tidak ada pilihan lain bagi mereka, menjadi anak jalanan merupakan konsekuensi dari berbagai macam faktor (Setiawan, 2020) mulai dari kesulitan ekonomi (Engkus, 2019) maupun faktor lain seperti kehancuran keluarga. Penelitian ini pada dasarnya melihat konstruksi social anak jalanan perempuan dengan mendasarkan perspektif teori Berger. Berger dan Luckman mengatakan institusi masyarakat tercipta dan dipertahankan atau diubah melalui tindakan dan interaksi manusia (Berger, 1990). Meskipun masyarakat dan institusi sosial terlihat nyata secara objektif, namun pada kenyataan semuanya dibangun dalam definisi subyektif melalui proses interaksi. Objektivitas baru bisa terjadi melalui penegasan berulang-ulang yang diberikan oleh orang lain yang memiliki definisi subyektif yang sama. Pada tingkat generalitas yang paling tinggi, manusia menciptakan dunia dalam makna simbolis yang universal, yaitu pandangan hidupnya yang menyeluruh, yang memberi legitimasi dan mengatur bentuk-bentuk sosial serta memberi makna pada berbagai bidang kehidupannya (Putri et al., 2019).

Melalui sentuhan Hegel yakni tesis-antitesis-sintesis, Berger menemukan konsep untuk menghubungkan antara yang subyektif dan obyektif melalui konsep dialektika, yang dikenal dengan eksternalisasi-objektivasi-internalisasi (Upe, 2010). Proses internalisasi lebih merupakan penyerapan kembali dunia obyektif ke dalam kesadaran sedemikian rupa sehingga subyektif individu dipengaruhi oleh struktur dunia sosial. Berbagai macam unsur dari dunia yang telah terobyektifkan tersebut akan ditangkap sebagai gejala realitas di luar kesadarannya, sekaligus sebagai gejala internal bagi kesadaran (Basrowi, 2002). Melalui internalisasi, manusia menjadi hasil dari masyarakat. Bagi Berger, realitas itu tidak dibentuk secara ilmiah, tidak juga sesuatu yang diturunkan oleh Tuhan. Tetapi sebaliknya, ia dibentuk dan dikonstruksi. Dengan pemahaman semacam ini, realitas berwajah ganda atau plural. Setiap orang bisa mempunyai konstruksi yang berbeda-beda atas suatu realitas. Setiap orang yang mempunyai pengalaman, preferensi, pendidikan tertentu dan lingkungan pergaulan atau sosial tertentu akan menafsirkan realitas sosial itu dengan konstruksinya masing-masing (Aji \& Kausan, 2020).

\section{METODE PENELITIAN}

Jenis pendekatan dalam penelitian ini yakni kualitatif deskriptif. Dengan teknik penentuan sampel menggunakan accidental yang diteruskan dengan purposive sampling atau sampel dengan didasarkan pada kriteria tertentu (Salim \& Syahrum, 2012). Didasarkan pada kriteria: bersedia diwawancarai dan berumur antara 6-17 tahun, diizinkan diwawancarai oleh orang tua/yang mengawasi bila diawasi, sudah lama beraktivitas di jalanan ( $>3$ tahun), beraktivitas di jalanan di atas 7 jam sehari. Data penelitian diperoleh dari dua sumber utama yaitu hasil wawancara dan dokumen dari berbagai literature. Observasi juga dilakukan untuk mendapatkan gambaran berkaitan dengan aktivitas mereka di jalanan. Di akhir penulis menggunakan analisis deskriptif untuk mendapatkan hasil sesuai tujuan penelitian. 


\section{PEMBAHASAN}

\section{Karakteristik Anak Jalanan Perempuan di Pekanbaru}

Potret anak jalanan perempuan di Kota Pekanbaru begitu miris sebab keputusan untuk bekerja telah membuat mereka harus rela tidak mengenyam pendidikan, putus di tengah jalan, bahkan ada yang bekerja sambil bersekolah. Tidak ada pilihan lain mereka melakukannya untuk bertahan hidup dan mengubur dalam-dalam keinginan atau cita-citanya untuk masa depan yang cemerlang. Karakteristik subjek penelitian penulis gambarkan pada tabel berikut ini yang mencakup beberapa poin penting.

Tabel Karakteristik Subjek Penelitian

\begin{tabular}{|c|c|c|c|c|}
\hline Nama & Usia & $\begin{array}{c}\text { Latar Belakang } \\
\text { Pendidikan }\end{array}$ & Pekerjaan & Asal Daerah \\
\hline RN & 14 tahun & Tidak tamat SD & Menjual Koran & Sumater Utara \\
\hline BA & 15 tahun & Lulus SD & Menjual Tissue & Pekanbaru \\
\hline TA & 13 tahun & Putus SMP & Pengamen & Sumatera Barat \\
\hline WI & 14 tahun & Putus SD & Menjual Tissue & Sumatera Utara \\
\hline LS & 12 tahun & $\begin{array}{c}\text { Masih } \\
\text { bersekolah SD }\end{array}$ & $\begin{array}{c}\text { Pedagang } \\
\text { Asongan }\end{array}$ & Pekanbaru \\
\hline RA & 14 tahun & Putus SD & Menjual Tissue & Pekanbaru \\
\hline
\end{tabular}

Sumber: Temuan Lapangan, 2019

Tabel di atas terlihat bahwa kelompok usia subjek dalam penelitian ini berada pada rentang 12-14 tahun. Umumnya subjek yang terpilih memiliki latar belakang pendidikan putus Sekolah Dasar, satu diantaranya masih bersekolah sementara sisanya sempat menamatkan Sekolah Dasar. Fakta yang terungkap bahwa sebagian anak jalanan perempuan dalam penelitian ini bukan warga asli Pekanbaru, mereka adalah pendatang dari beberapa provinsi tetangga seperti Sumatera Utara dan Sumatera Barat. Begitu pula yang keadaan di lapangan, selain yang menjadi subjek dalam penelitian ini, anak jalanan perempuan lainnya juga banyak yang bukan warga asli. Mereka melakukan migrasi bersama orang tuanya untuk meningkatkan taraf hidup di Pekanbaru dengan berbagai macam alasan. Diungkapkan oleh salah satu subjek sebagai berikut:

\section{WI (14): "Nggak tahu kenapa kesini kelas tiga SD kesini dulu tinggalnya nggak disini terus pindah karena nggak bisa bayar mahal."}

Subjek WI (14) tidak dapat menjelaskan dengan pasti alasan mengapa sampai akhirnya mereka sekeluarga tinggal di Pekanbaru dan beraktivitas di jalanan. Guna mendapatkan informasi yang tepat maka dalam hal ini penulis seperti yang telah dijelaskan pada bagian metode menggunakan cara triangulasi kepada orang tua, kerabat, atau orang dekat yang bisa memberikan keterangan dengan akurasi seperti yang diharapkan. Maka penulis mewawancarai seorang ibu yang secara kebetulan merupakan orang tua dari salah satu subjek dalam penelitian ini. 
Ibu MH: "Ibu dari Sumbar merantau saja di Pekanbaru. Ada anak bujangku duluan merantau disini jadi ibu ikut. Di Sumbar tak ada saudara karena ibu anak tunggal jadi akbirnya ke Pekanbaru anak bujangku yang ngajak ma sini aja cari kerjaan disini. Ya akrbinya merantau sampai sekarang udah lima tabun."

Budaya merantau memang menjadi ciri khas dalam kaitannya merubah kondisi sosial ekonomi seseorang. Merantau dimaksudkan agar di daerah rantau mereka mendapatkan pekerjaan dan kehidupan yang layak tetapi tidak semua harapan itu terwujud. Kegagalan beradaptasi dengan iklim kehidupan kota yang tidak disertai keahlian membuat perantau tidak bisa mendapatkan penghidupan layak yang pada akhirnya memutuskan melakukan pekerjaan seadanya yang tidak menuntut keahlian khusus dan modal. Demikian halnya yang dikatakan oleh Ibu MH orang tua salah satu subjek penelitian, yang mengatakan alasan mereka tinggal di Pekanbaru dan bekerja disini tidak lain karena alasan ekonomi. Ini berlaku pula pada subjek lain sebagai pendatang di Pekanbaru yang mayoritas mengingingkan penghidupan yang layak.

\section{Proses Konstruksi Diri Anak Jalanan Perempuan di Pekanbaru Eksternalisasi}

Proses eksternalisasi merupakan suatu keadaan dimana subjek melakukan proses menyesuaikan diri dengan lingkungan sekitar (sosio-kultural). Dari proses eksternalisasi individu akan mendapatkan banyak hal berupa informasi maupun pengetahuan yang pada akhirnya akan memberikan pengaruh terhadap pengambilan keputusan individu tersebut (Lestari et al., 2018). Penelitian yang dilakukan oleh Risdawati Ahmad, dkk (2018) mengidentifikasi dua bentuk eksternalisasi pada keluarga pengemis dan bisa berlaku bagi pekerjaan serupa jalanan lainnya. Pertama, proses eksternalisasi bisa terjadi dari lingkungan sekitar yang menurun dan dialami oleh orang tua individu kemudian terjadi pewarisan kepada anak-anaknya. Kedua, proses eksternalisasi bisa saja dialami hanya murni faktor lingkungan sekitar yang kemudian hal itu membuat individu tergerak melakukan aktivitas serupa (Ahmad et al., 2018). Kondisi serupa juga sama dialami oleh subjek dalam penelitian ini. Ada dua model eksternalisasi yang terungkap. Pertama, subjek yang menjadi anak jalanan karena diajak orang tua atau kerabat dekat yang terlebih dahulu sudah melakukan aktivitas di jalanan. Mereka yang lebih dulu beraktivitas di jalanan itu memberikan rangsangan kepada subjek untuk ikut melakukan pekerjaan yang sama dengan berbagai iming-iming. Salah satu diungkapkan oleh subjek berikut ini:

LS (12): "Yang itulah mamak suruh. disurub mamak bang. Kerja aja katanya biar bisa dapat uang beli jajan."

Subjek LS (12) menuturkan bahwa ia diperintah oleh orang tuanya untuk bekerja agar mendapatan uang. Sebagai anak yang berusaha berbakti kepada orang tuanya LS menuruti perintah orang tuanya itu dengan bekerja sebagai pedagang asongan. Ini dipilih menurutnya lantaran sedikit anak kecil yang berdagang sebagai penjual asongan sehingga masih ada peluang jika LS melakukan pekerjaan tersebut 
bisa membawa keuntungan. Pada model pertama ini orang terdekat memiliki peranan penting dalam proses seorang anak pada akhirnya memutuskan untuk turun ke jalan. Orang terdekat bukan saja menyuruh dengan otoriter tetapi suruhan itu dilakukan dengan diawali oleh iming-iming uang. Ada semacam nilai yang ditanamkan dalam diri sang anak sehingga menganggap bahwa turun ke jalan merupakan pekerjaan yang benar-benar dapat memberinya penghasilan (Sukmaningrum \& Faizah, 2019). Maka hal ini sangat cocok untuk menjadi rangsangan bagi sang anak yang notabene masih membutuhkan banyak uang jajan agar sama seperti temanteman lainnya. Anak jalanan dengan latar belakang keluarga yang memiliki kerentanan social-ekonomi tinggi dan masuk dalam kelompok marginal perkotaan (Setiawan, 2020) akan memiliki potensi besar melakukan suatu pemaksaan atau pengarahan untuk melakukan tindakan tertentu yang dianggap menguntungkan.

Desakan dari orang terdekat kepada sang anak untuk turut bekerja di jalanan akan diperparah karena dua dari subjek memang bertempat tinggal di kawasan kumuh. Mereka meninggali ruko kosong di seputaran Simpang SKA tepatnya berdekatan dengan patung kuda. Kawasan tersebut merupakan ruko yang sudah tidak terpakai yang kemudian disulap untuk dijadikan kamar atau tempat tidur. Ada banyak sekali orang yang tidur disana yang jumlahnya lebih dari 20-an orang dengan beberapa kepala keluarga. Potret lingkungan tempat tinggal yang juga dikeilingi dengan orang-orang bekerja di jalanan baik sebagai pengemis, penjual koran, penjual asongan, penjual tissue, pengamen, dan sebagainya turut memberikan tekanan yang semakin kuat kepada orang tua untuk memaksa anaknya melakukan pekerjaan yang sama. Pada akhirnya sang anak sulit untuk menolak karena selain dipaksa oleh orang tua dengan berbagai cara ia juga terpengaruh oleh teman sepermainan yang telah lama bekerja di jalanan.

Tidak ada yang bisa memberikan jawaban pasti mengapa bekas ruko tersebut kemudian menjadi kawasan kumuh yang ditempati puluhan anak jalanan beserta orang tua atau orang terdekatnya. Namun, WI (14) menuturkan umumnya orang yang tinggal di tempat tersebut adalah mereka yang semula mengontrak tetapi tidak mampu membayar uang sewa yang pada akhirnya memutuskan untuk tinggal di tempat itu dengan berbaur bersama puluhan orang dalam satu gedung yang terbagi menjadi beberapa kamar.

Kedua, subjek memilih turun ke jalan karena keinginan diri sendiri melihat realitas yang ada di sekelilingnya tanpa dipengaruhi oleh ajakan orang tua atau kerabat seperti pada model yang pertama. Terlalu seringnya subjek bergaul dan melihat sekelilingnya menjalankan pekerjaan di jalanan perlahan turut membentuk keinginan melakukan hal serupa dari keinginan diri sendiri (Luthfiana et al., 2019). Ada juga para orang tua atau orang tua asuh yang tidak memberikan dorongan kepada anaknya untuk bekerja di jalanan meskipun mereka juga tinggal di tempat yang ramai anak-anak jalanan. Model ini lebih menekankan rasa empati dari seorang anak melihat keadaan ekonomi keluarga. Seorang anak termasuk subjek dalam penelitian ini merasa bahwa dengan turunnya mereka ke jalanan, bekerja menjual 
jasa ataupun barang itu akan membantu keuangan keluarga. Terlebih bagi anak atau subjek yang hidup hanya ditemani oleh satu orang tua saja sementara orang tuanya tersebut sudah beranjak tua yang tidak bisa lagi bekerja seperti biasanya. Sehingga ini membuat sang anak merasa harus turun ke jalan demi membantu ekonomi.

Kondisi ini dialami oleh subjek bernama TA (13) yang telah lama ditinggal oleh Ibunya. Ia hidup bersama ayah dan saudara laki-lakinya. Untuk membantu keuangan keluarga ia terpaksa harus bekerja karena ayahnya juga sakit-sakitan perlu uang untuk membeli obat. TA mengatakan:

"amak la ndak ado kini. Meninggal tigo tahun lalu. Kalau apak ala tuo ndak bisa karajo sakik-sakit taruih dulu apak jualan sayur kini la tuo ndak sanggup bajalan."

Keadaan ini memaksanya untuk bekerja dijalanan dengan menjadi pengamen untuk dapat membiayai kebutuhan ayahnya terutama obat-obatan. Model semacam ini bisa dialami oleh individu yang benar-benar dalam keadaan ekonomi memprihatinkan dan tekanan hidup yang begitu besar. Pada posisi tertekan dengan beban hidup yang besar itu kemudian membangkitkan naluri bekerja demi mencukupi segala macam kebutuhan. Namun, penekanannya adalah pada keadaan sekitar yang juga tidak mampu untuk memberikan jaminan sosial kepada dirinya dan keluarga untuk hidup. Tidak ada lagi yang bisa diandal-kan untuk membantunya. Sang anak murni melalui tahap pengamatan langsung kepada realitas sekitar sebelum kemudian ia memutuskan untuk bekerja di jalanan di samping tekanan yang memang sudah ada dalam kehidupannya. Terdapat pula yang tipenya karena terlalu sering melihat aktivitas orang-orang di sekelilingnya, mereka bekerja di jalanan kemudian mendapatkan uang lalu uang itu digunakan untuk berbelanja, membeli jajan atau keperluan lainnya. Pengamatan yang dilakukan oleh individu ini kemudian akan mendorongnya untuk melakukan penye-suaian dengan mempelajari lebih dalam baik bertanya maupun berpartisipasi aktif misalnya ikut teman atau orang lain turun ke jalanan. Maka pada titik dimana individu tersebut merasa dengan begitu ia bisa mendapatkan uang, ia akan mengerjakannya sendiri dengan membawa bekal pengetahuan yang sudah didapatkan dari pengamatan dan keterlibatannya tersebut.

Dua model ini memliki perbedaan yang mendasar mengenai proses eksternalisasi yang terjadi. Model pertama subjek menjadi anak jalanan karena faktor pengaruh lingkungan sosial yang diwariskan kepada orang tua atau kerabat dekatnya. Sementara pada model kedua, yang mendorong mengapa subjek menjadi anak jalanan tidak lain karena faktor internal keluarganya (Armita, 2016). Keluarga dekat menanamkan nilai-nilai yang begitu dalam kepada anaknya untuk bekerja di jalanan dan menjadi anak jalanan yang baik dalam artian bisa mendapatkan banyak uang melalui strategi tertentu.

\section{Ojektivasi}

Tahapan kedua setelah proses eksternalisasi yakni individu atau subjek mengalami proses objektivasi. Menurut Berger, pada tahapan ini seseorang mendapatkan 
realitas objektifnya berupa produk material maupun non material dan semakin melembaga atau mengalami proses institusional (Ahmad et al., 2018). Pada dasarnya, subjek yang menjadi anak jalanan maupun orang tua dan kerabat dekat sadar pekerjaan mereka tidak dibenarkan. Bahkan sering kali mereka dihantui rasa takut akan ditertibkan, dijatuhi sanksi, maupun dikembalikan ke daerah asal. Mereka juga sadar bahwa pendapat masyarakat tentang orang-orang yang beraktivitas di jalanan termasuk anak jalanan tersebut cenderung negatif, dianggap sebagai sampah masyarakat yang menganggu ketertiban umum.

Namun, tidak ada jalan lain yang bisa mereka lakukan. Apa yang dilakukan tersebut merupakan pilihan akibat situasi yang sulit, tentang keadaan ekonomi keluarga dan sulitnya mendapatkan pekerjaan. Subjek dan para orang tua atau yang biasanya menjaga juga sangat berharap di hati kecil mereka agar masyarakat tidak memperlakukan mereka dengan tidak manusiawi meskipun telah menganggu ketertiban umum. Paling tidak ketika masyarakat tidak berniat membeli dagangan atau menggunakan jasa mereka tidak lantas memberikan perlakuan yang buruk, seperti mengejek atau bahkan meludahi. Sebab hal semacam ini pernah mereka alami bahkan sering kali anak-anak mereka mendapat ocehan karena menganggu kenyamanan umum.

Tahapan objektivasi merupakan proses perwujudan dari eksternalisasi. Di tahap ini subjek mulai melakukan apa yang ia pelajari dan dapatkan dari pengalaman sebelumnya. Setiap tindakan yang sering diulangi pada tahap eksternalisasi akan membentuk sebuah pola, dan biasanya itu akan dilakukan di kemudian hari dengan cara yang sama persis maupun mengkombinasikan dengan inovasi yang baru (Suzanna, 2018). Tahap objektivasi dilalui dengan proses yang panjang. Awalnya dialami oleh orang tua baik ibu maupun ayah atau orang terdekat yang terlebih dahulu bekerja di jalanan menjadi pengemis, penjual koran dan sebagainya. Mereka telah melalui tahap eksternalisasi dan mulai mengamalkan pengetahuan-pengetahuan hasil dari pengaruh yang didapatkan. Perlahan ia menjadi seorang yang bekerja di jalanan dan pada titik tersebut pula sudah mulai terjadi penyesuaian budaya. Jika ingin menjadi pengemis maka penampilannya harus benar-benar menimbulkan kesan prihatin, misalnya pura-pura sakit atau tangannya putus. Ini dilakukan tidak lebih untuk memunculkan rasa empati dari orang-orang yang melihat lalu memberinya sejumlah uang. Tahap objektivasi dilakukan dengan berbagai macam cara, yang jelas pada tahap ini seseorang akan berusaha bagaimanapun caranya untuk menimbulkan kesan keprihatinan dari orang banyak dilakukan dengan merubah penampilan fisik, seperti wajah yang dibuat kusam dan kotor, rambut dibuat acakacakan, sengaja memakai baju compang-camping sambil membawa property. Namun, perubahan terhadap penampilan fisik ini juga tergantung pada jenis pekerjaan yang dilakukan. Subjek TA misalnya, ia bekerja menjadi pengamen. Maka kemudian ia berfikir untuk menimbulkan kesan agar orang lain tertarik, yang ia lakukan adalah dengan berpenampilan sedikit lebih cantik untuk menarik perhatian. Ini juga dilakukan dengan berbeda-beda setiap orang tergantung jenis pekerjaan dan 
bagaimana pula ia mempersepsikan pekerjaan tersebut.

\section{Internalisasi}

Tahapan terakhir yang dilalui dalam konstruksi sosial yakni internalisasi. Tahap ini diartikan sebagai pemahaman oleh individu tentang realitas sebagai sesuatu yang penuh makna atau lebih kepada penyerapan kembali dunia yang objektif dalam sebuah kesadaran, dengan kata lain realitas sosial berada dalam diri manusia dan dengan cara itu manusia akan teridentifikasi dalam dunia sosio-kultural (Putri et al., 2019). Di tahap ini pula ada proses sosialisasi yang dilakukan untuk menjaga atau melestarikan jati diri sebagai anak jalanan perempuan. Sama dalam tatanan teoritis, bahwa sosialisasi terdapat dua bentuk yakni primer dan sekunder. Sosialisasi primer dialami oleh seorang subjek dalam keluarga. Sosialisasi sekunder ialah yang dialami pada lingkungan sosial dimana subjek tinggal. Proses internalisasi pada tahap sekunder dilakukan oleh orang tua atau kerabat dekat dengan menanamkan nilainilai, memberikan pengetahuan-pengetahuan, rangsangan, dan contoh-contoh kepada subjek untuk menjadi anak jalanan perempuan yang baik agar mendapatkan banyak uang. Orang tua atau kerabat bagaimana caranya akan tetap memberikan sugesti kepada subjek agar tetap melakukan pekerjaan tersebut. Sementara proses sosialisasi sekunder dapat dikatakan sebagai proses lanjutan dari sosialisasi primer. Subjek bukan saja mendapatkan nilai-nilai menjadi anak jalanan dari orang tua maupun kerabat dekatnya, tetapi juga dari lingkungan sosial di luar ranah privat subjek seperti teman sepermain. Teman sepermainan memberikan pengaruh yang kuat dalam proses internalisasi sekunder karena lazimnya anak-anak biasanya mereka lebih mudah menerima segala sesuatu dari teman sepermainan karena ada nilai-nilai menyenangkan serta menguntungkan.

\section{PENUTUP}

Menjadi anak jalanan perempuan merupakan sebuah proses panjang melalui eksternalisasi (lingkungan sosial terkesternalisasi oleh orang terdekat subjek, kemudian diwariskan pada subjek dan subjek melakukan eksternalisasi secara langsung dengan lingkungan sosialnya), objektivasi (subjek mulai melakukan atau mengerjakan pekerjaan jalanan sama seperti yang ia lihat dan dapatkan dari hasil eksternalisasi), dan terakhir internalisasi (subjek mulai melembagakan, melestarikan dan mempertahankan pekerjaannya tersebut dengan menerapkan suatu strategi khusus, subjek juga telah merasa sangat nyaman dengan kondisi saat ini karena mendapatkan banyak keuntungan meskipun mereka tahu hal tersebut tidak dibenarkan secara norma dalam masyarakat). Enam subjek penelitian terbagi menjadi dua kategori. Pertama, memiliki pandangan yang optimis akan dapat meraih cita-cita dan harapannya dengan berbagai macam usaha. Kedua, berpandangan sebaliknya, tidak begitu optimis dan cenderung berpasrah untuk dapat meraih masa depan dan cita-citanya karena tidak mendapatkan ruang berekspresi dari orang terdekatnya. 


\section{DAFTAR PUSTAKA}

Ahmad, R., Irchamniah, N., Pujiana, O., \& Purwasih, J. H. G. (2018). Konstruksi Sosial dalam Keluarga Pengemis di Kecamatan Sukun Kota Malang. Sosiologi Pendidikan Humanis, 3(1), 47-54. http://journal2.um.ac.id/index.php/jsph

Aji, A. P., \& Kausan, B. Y. (2020). Komunitas Satoe Atap: Produksi Ruang Sosial Bagi Anak Jalanan di Kawasan Simpang Lima Semarang. Analisa Sosiologi: Edisi Khusus Sosiologi Perkotaan, 9, 93-107. https://jurnal.uns.ac.id/jas/article/view/39816

Armita, P. (2016). Meningkatkan Kesejahteraan Sosial Anak Jalanan dengan Teori Self Esteem. PKS, 15(4), 377-386. ejournal.kemsos.go.id

Basri, \& Yoserizal. (2019). Identifikasi Faktor Pendorong Anak Perempuan Beraktivitas Di Jalanan: Studi Terhadap Anak Jalanan Di Kota Pekanbaru. Antropologi: Isu-Isu Sosial Budaya, 21(1), 81-91. jurnalantropologi.fisip.unand.ac.id

Basrowi, S. (2002). Metode Penelitian Kualitatif Prespektif Mikro. Insan Cendikian.

Berger. (1990). Tafsir Sosial Atas Kenyataan. LP3S.

Engkus. (2019). Implementasi Kebijakan Perlindungan Anak Jalanan di Kota Bandung. Media Bina Ilmiah, 14(3), 2077-2084. http:/ / ejurnal.binawakarya.or.id/index.php/MBI

Lestari, W., Kristiana, L., \& Paramita, A. (2018). Stunting: Studi Konstruksi Sosial Masyarakat Perdesaan dan Perkotaan Terkait Gizi dan Pola Pengasuhan Balita di Kabupaten Jember. Masalah-Masalah Sosial, 9(1), 17-33. http://jurnal.dpr.go.id/index.php/aspirasi/index

Luthfiana, N., Oktaviana, S. D., \& Rakhma, N. (2019). Representasi Diri Gelandangan di Kota Semarang. Intuisi: Jurnal Psikologi Ilmiah, 11(2), 150_ 157. http://journal.unnes.ac.id/nju/index.php/INTUISI

Putri, L. D., Annisarizki, \& Mulyasih, R. (2019). Pemaknaan Melalui Konstruksi Sosial yang Dibangun Oleh Wartawan dalam Menyebarkan Ujaran Melalui Facebook. Lontar, 7(1), 25-35. e-journal.lppmunsera.org

Salim, \& Syahrum. (2012). Metodologi Penelitian (5th ed.). Ciptapustaka Media.

Setiawan, H. (2020). Fenomena Gelandangan Pengemis sebagai Dampak Disparitas Pembangunan Kawasan Urban dan Rural di Daerah Istimewa Yogyakarta. Moderat, 6(2), 361-375. https://jurnal.unigal.ac.id/index.php/moderat

Siswanto, \& Widodo, A. (2019). Pembinaan Anak Jalanan Melalui Pola Asuh di Rumah Singgah dan Belajar (RSB) Diponegoro Sleman Yogyakarta. Hisbah: Jurnal Bimbingan Konseling Dan Dakwah Islam, 16(1), 59-73. https://journal.ipm2kpe.or.id/index.php/JKS/article/view/1329

Sukmaningrum, P. S., \& Faizah, S. I. (2019). Penguatan Ekonomi Orang Tua pada Keluarga Anak Jalanan (Studi Kasus: Sanggar Alang-Alang Surabaya). Sosial Humaniora, 12(2), 120-130. www.iptek.its.ac.id 
Suzanna. (2018). Pengalaman Perubahan Konsep Diri pada Anak Jalanan di Panti Sosial Rehabilitasi Gelandangan, Pengemis dan Terlantar di Sumatera Selatan Tahun 2016. Keperawatan Sriwijaya, 5(1), 40-57. ejournal.unsri.ac.id.

Upe, A. (2010). Tradisi Aliran dalam Sosiologi: dari Filosofi Postivistike ke Postpositivistik. Jakarta: RajaGrafindo Persada. 